\title{
5. Under Two Flags: Encounters with Israel, Merdeka and the Promised Land in Tanah Papua ${ }^{1}$
}

\author{
Henri Myrttinen
}

On 19 October 2011, the Third Papuan Congress, held in the outskirts of the Papuan provincial capital Jayapura, ended in chaos and bloodshed. During the three-day congress, several thousand participants had discussed the current situation in Tanah Papua, how to improve the lives of the indigenous 'sons of the soil' as well as their fears of social, cultural, religious and economic marginalisation. ${ }^{2}$ The answer was not a new one: not for the first time, the Land of Papua proclaimed its independence from Indonesia, a new government was declared and, amongst other measures, the Dutch New Guinea Guilder was introduced as the national currency (GKI 2011). ${ }^{3}$ The Indonesian security forces reacted to this act of secession by storming the meeting, arresting and physically abusing several hundred participants. According to the national commission of human rights, at least three, possibly six Papuan civilians were killed in the process under unclear circumstances.

I argue that symbols - often with a heavily religious/mythological overtone - play a central role in Papuan nationalist politics. In order to gain a better understanding of Papuan aspirations and dreams of a better future one needs not to merely look at socio-economic statistics but also to investigate symbolic offerings. The Declaration of Independence itself was a heavily symbolic act, but it was buttressed by other symbols seen as being imbued with power and meaning. Why was the congress opened with not just the waving of the

\footnotetext{
1 The chapter is an adaptation of a paper presented at the 'Becoming Like The State' panel at the Annual Meeting of the American Anthropological Association, 16-20 November, 2011, Montréal. The author would like to thank Jaap Timmer and Daniel Fisher who organised the panel and the Nordic Institute of Asian Studies in Copenhagen who hosted him at the time of writing. The title is a nod to Benedict Anderson's Under Three Flags (2005), an excellent study of anti-colonial imaginaries and struggles for national independence. 2 There is a certain amount of potential confusion surrounding the names used to refer to the western part of the island of New Guinea. The area is divided into the two Indonesian provinces of Papua and West Papua, which were previously the province of Irian Jaya, later renamed Papua. Somewhat confusingly, both in Papuan society and outside, both provinces are often lumped together either as 'Papua' or 'West Papua' (Papua Barat). In an effort to avoid confusion, I will use the terms West Papua and Papua to refer to the respective provinces and the adjective 'Papuan' as pertaining to social, political, economic, cultural, etc. dynamics within the indigenous community in both provinces. I will use the term Tanah Papua (Land of Papua) to refer to the area covered by the two provinces jointly.

3 As discussed in the final section of the chapter, Israeli national symbols are not the only ones seen as having a certain potency; also old Dutch symbols are often utilised. As Jaap Timmer (2000: 36) points out, an exaggerated value is often ascribed to the old Dutch New Guinea Guilder in Papua/West Papua. As Chauvel (2006: 181) notes, 'Papuan memories of the Netherlands' administration have become rosier with the passage of time, in part as a mirror of their experience of Indonesian governance since 1963'.
} 
outlawed Papuan Morning Star flag (Bintang Kejora) but also the Israeli national flag $?^{4}$ Why were Indonesian citizens of Melanesian descent expressing their discontent with their current political status through the national symbols of a state over 10,000 kilometres away?

Though I had been to the Indonesian provinces of Papua and West Papua several times previously, it was only during a visit in early 2009 that the issue of 'Israel' in Papuan society and political discourse piqued my interest. It was both the time of Israel's attack on the Gaza Strip ('Operation Cast Lead') and an increased sense of fear of 'Islamisation' in Papuan society. ${ }^{5}$ During this visit, I noticed the emergence of Star of David graffiti in the streets of the provincial capital Jayapura, of indigenous Papuans sporting pro-Israel t-shirts, of functionaries of the Christian congregations using Israeli and Jewish symbols as wallpaper on their laptops and smart phones. I started paying more attention to references to the Middle East both in the local political discourse and in everyday life.

Over the next few years during which I visited the two provinces, I started noticing references more frequently - Israeli flags painted on shop fronts, as stickers on cars and mopeds, on displays at football matches of the local team Persipura; increased pilgrimages by Christian Papuans to the Holy Land; ${ }^{6}$ as well as comparisons between Tanah Papua and the Holy Land made at different levels of societal discourse. Nor was this phenomenon restricted to Papua and West Papua - a similar 'Israel boom' also became visible in predominantly Protestant North Sulawesi and in Catholic Timor-Leste, though under somewhat different circumstances and very different readings. ${ }^{7}$

Almost as if to mirror this, the Middle East theme has also been used by Indonesian Muslims in their attention to Tanah Papua. Indonesian Islamist websites such as Suara Islam and Sabili argue that Papua (or Nuu War) was Muslim before it was Christian. The websites show pictures of Islamic proselytisers in Papua clad in Palestinian khaffiyahs. The very last mosque on the Indonesian side

\footnotetext{
4 A video of Sampari ('Morning Star') dancers at the opening ceremony of the Third Papuan Congress is accessible at http://www.youtube.com/watch? $\mathrm{v}=\mathrm{wUQWulFz2nM}$ and the Israeli national flag is visible several times at 0:24, 1:56 and 2:20, respectively.

5 Indigenous Papuans are, for the most part, Protestants and Catholics, while a majority (though not all) migrants from other parts of Indonesia tend to be Muslim. The issue is a very sensitive one and reliable figures are difficult to come by. In many of the urban centres of the two provinces, migrants quite possibly are in the majority and play a dominant role in the economy.

6 Given the political sensitivities around the issue, I would like to clarify that in using the term Israel I refer to the State of Israel and in using the term 'The Holy Land' to the somewhat vaguely defined geographical area commonly seen as being sacred in the Christian tradition and which is currently for the most part administered by the State of Israel and the Palestinian Authority.

7 Regarding Timor-Leste, see for example Kammen (2009: 400-401,404) and Myrttinen (2010: 263), while for North Sulawesi, see for example Swazey 2010. Israel/Holy Land-related political imaginaries are, however, neither restricted geographically to the Indonesian archipelago nor temporally to the present day, but can be found in a wide variety of contexts, from radical German Anabaptists in the 1500s (Kirchhoff 1973) over Ronald Reagan (1984) to present-day Solomon Island villagers (Timmer 2008).
} 
before the Papua New Guinea (PNG) border on the road between Jayapura and Vanimo is called the al-Aqsha Mosque, in reference to the eponymous mosque in Jerusalem, which is the third holiest site in Islam. ${ }^{8}$

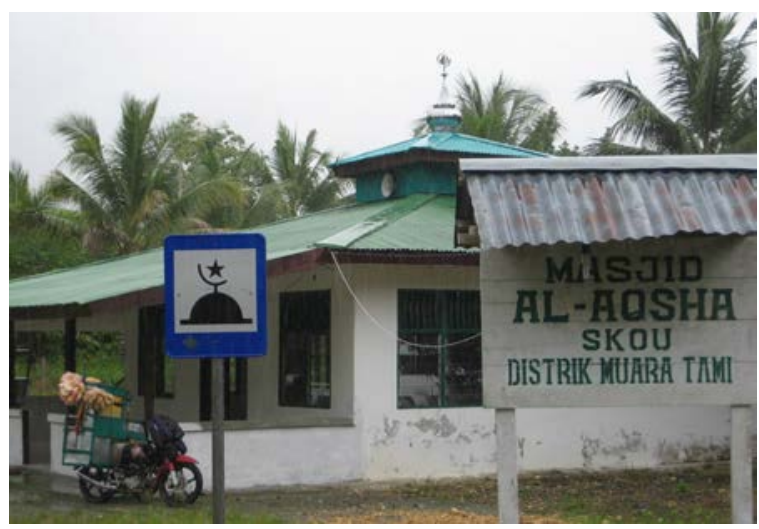

\section{Figure 5.1. Al-Aqsha Mosque, Keerom Regency, Papua.}

Source: Henri Myrttinen.

Though Israel seems to be increasingly prominent in Papuan discourses, it needs to be stated to avoid any misconceptions that the State of Israel has not actually been showing any interest in the issues of Papua/West Papua. ${ }^{9}$ Indonesia and Israel do not maintain diplomatic relations and there is no official presence in the country. Israeli civil society groups have also not been at the forefront of demands to place Papuan issues onto the agenda. The 'special relationship', therefore, seems to me to be a decidedly one-way affair.

This chapter aims to chart some of the ways in which 'Israel' has been and is being used in Papuan discourses. After sketching some of the conditions that contribute to Papuan political discourses I will look at three different ways in which the relationship of Tanah Papua and Israel/The Holy Land manifests itself in these discourses:

1. Israel as a perceived ally, and as a projection surface of hopes and aspirations,

8 More generally, the Israeli-Palestinian conflict, Jewish history (especially with regard to the Holocaust) as well as often elaborate conspiracy theories of all shades linked to radical Islam, Judaism and Nazism seem to hold a special sway over Indonesian readers, at least judging by what is on offer at bookstores. Though not representative, in a quick browse through the rather limited political and social science section of the main book store in Jayapura, the capital of Papua province, on a visit in 2011, I found books on Hitler's alleged secret post-World War II life in Indonesia, on Jewish World Conspiracies, on purported ties between Nazis and al-Qaeda, on why Malaysia is supposedly a Jewish state and on why Barack Obama allegedly is the 'Black Hitler'.

9 A possible exception was the reception of an OPM representative by Israel in the 1970s, though the source, the late John Otto Ondawame, himself an OPM representative, casts a degree of doubt on to the question whether the meeting actually ever took place (Ondawame 2010). 
2. Spiritual links between Israel/the Holy Land and Papua, and

3. Israel/the Holy Land as (metaphor for) Tanah Papua.

In the first discourse, the State of Israel is mainly perceived as a political ally of the Papuans, with both deemed as sharing a common cause, such as a struggle against more powerful (Muslim) neighbours. The second discourse focuses more on spiritual links established through Christianity and readings of Biblical texts in which the Holy Land itself, along with Judeo-Christian symbols, takes a central place. The third discourse goes further, with Israel/the Holy Land becoming a metaphor of the Land of Papua - or even merging with it. It should be noted that in the interviews and discussions I conducted, there was not always a clear distinction made between the different approaches and they often flowed into one another.

This chapter is based on interviews carried out with Papuan political actors (these were mostly from outside Indonesian state structures), church representatives (both Papuan and international), civil society actors (both Papuan and international) and researchers. While the bulk of the interviews were carried out in Papua and West Papua provinces, others were carried out in other parts of Indonesia, Australia, Papua New Guinea, Vanuatu and various European countries over the course of 2009-2011. Rather than being the result of a fully fledged research project, this is more a sketch based on notes and observations made over the years, and should be seen as such. This has in one part been due to personal limitations, but also to a great part due to the restrictions placed by the Indonesian central government on foreigners working or researching in the two provinces of Papua and West Papua. Given the sensitivity of the issues discussed here, all interviewees have been anonymised.

In this chapter I sketch undercurrents in contemporary Papuan thought and discourse, but these trajectories are not wholly representative of Papuan ideological orientations. A number of potential respondents reacted with what I felt was a certain degree of impatience and irritation to my questions on 'Israel', either declaring it more or less irrelevant or on occasion muttering darkly about 'cargoism' but refusing to elaborate. Both the English term and the Indonesian term, 'kargoisme' can have pejorative undertones of racial and evolutionist stereotypes of Papuans (and other Melanesians) as being 'backward' (tertinggal) or 'still stupid' (masih bodoh), or of hanging on to pre-Christian beliefs. ${ }^{10}$ The background of my interviewees often shaped responses, with more politically minded people using political analogies, those with more religious backgrounds

10 As Holger Jebens (2004: 4) points out '[...] the negative connotations of primitivism and irrationality derived from the term "cargo cult" first being coined by planters, colonial administrators, and missionaries in order to denote and dismiss whatever they saw as obstacles to their respective intentions. These negative connotations are also characteristic of indigenous discourses in that they can be detected when Melanesians talk about cargo cults themselves.' 
more likely to use Biblical metaphors and so on. Many of the more mainstream Christians (e.g. from church organisations) did not take a kind view of more 'cargoist' interpretations (see KPKC 2009).

Identification with Israel and the Holy Land is clearly evident in Papuan discourse, as is the even more ubiquitous discussion of merdeka, but as the chapter demonstrates, there are multiple ways in which these links are understood and configured. Also, not all associations with Israel or even merdeka are necessarily political in the conventional sense of the word, but are more of a spiritual nature or refer to freedom from want and fear in a more material sense.

\section{Political discourses of discontent}

Since its controversial integration into the Indonesian state over the years 1962-69, what now constitutes the provinces of Papua and West Papua has been engulfed in a political and military struggle over the status of the territory. While Indonesia considers the territory to be an inalienable part of the republic, significant voices of Papuans inside the territory and in exile demand a revisiting of the controversial 1969 'Act of Free Choice', which sealed the integration into the Indonesian state. In addition to voices demanding self-determination, the low-level insurgency of the Organisasi Papua Merdeka (OPM) has since 1964 sought to militarily challenge the status quo. In addition to the over-arching issue of the political status of the territory, Papuan debates often focus on issues of both real and perceived social, economic and political exclusion; fears of 'Islamisation' linked to the influx of migrants from other parts of Indonesia; exploitation of the national resources of the two provinces by outsiders and acts of discrimination and oppression at the hands of members of the Indonesian security forces (see Hernawan in this volume). ${ }^{11}$ There is a pervasive sense that the Papuan nation as a whole is under threat and references to 'genocide' are not uncommon.

I found pro-Israel references in Papuan discourse to be closely linked to discontent over the political status of the territory and Muslim migration to the area. Many of the websites and Facebook pages linking Papua and Israel, for example, include calls for Papuan self-determination (see also Figure 2 and Figure 3). This discontent stems from the history of the incorporation of what was then Dutch West New Guinea into Indonesia in 1961-69 and subsequent military repression (see for

\footnotetext{
11 The use of the term 'real and perceived' is in no way meant to question, diminish or in any other way downplay the very real and serious issues of socio-economic marginalisation, lack of access to basic services, serious environmental degradation, land grabbing, security fears and the like faced by the inhabitants of Tanah Papua, be they indigenous or migrants, on a daily basis. Rather, what I want to point out is that these are augmented by perceived fears and threats emanating from a socio-political discourse both in Papua and in Indonesia more generally in which rumour, conspiracies and innuendo play a central role (see for example Bubandt, 2008).
} 
example Drooglever 2005 and Saltford 2003 for a history of the transfer). Since the mid-1960s, the Organisasi Papua Merdeka (OPM - Free Papua Organisation) has waged a small-scale war of independence. While the Indonesian term 'merdeka' is usually translated as 'independence' in English, I found the term to be used much more ambiguously in my interviews (see also Golden 2003 and Kirksey 2012: 16-18 for a discussion of the term). The vast majority of my respondents were highly critical of the current socio-economic, political and cultural predicament of both the indigenous Papuan nation/people (Bangsa Papua) and 'The Land of Papua' (Tanah Papua - which covers both provinces), placing much of the blame squarely with the Indonesian central government. Nonetheless, merdeka was understood in a number of ways, including freedom from want, spiritual freedom, liberation in the religious sense, self-determination and various forms of autonomy, confederation or full independence.

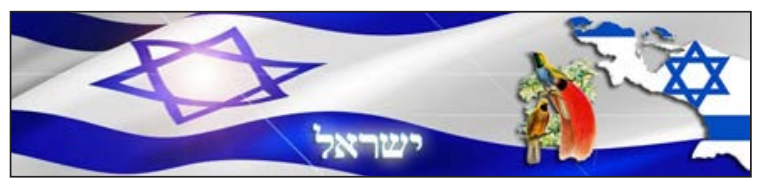

Figure 5.2. Banner of a Papuan website with an outline of Tanah Papua in Israeli colours, Birds of Paradise and 'Israel' in Hebrew.

Source: http://papua-israel.blogspot.com (accessed 16.01.15).

My interviews were carried out mostly in a time of heightened political activity in the two provinces, which have enjoyed close to a decade of special autonomy (Otonomi Khusus - Otsus). Although Otsus has, in theory, brought the two provinces unprecedented financial largesse and political power, the vast majority of Papuans I have interviewed over the years in both provinces, regardless of their social and political backgrounds, viewed the autonomy package as a failure. ${ }^{12}$ In 2010, a coalition of civil society organisations symbolically returned Otsus to the central government, demanding a review of the package, a call echoed in 2011 by a high-level coalition of local churches. In parallel, my interviewees often conveyed an increasing sense of anxiety over the possibility of communal conflict not just between Papuans and migrants but also between Papuans themselves, for example highland migrants and the local lowland population in urban centres. Since 2009, there have been numerous unresolved cases of

12 The implementation of Otsus is a highly contentious issue and most of my Papuan interlocutors considered it a failure and/or a plot hatched in Jakarta to dissuade Papuans from seeking merdeka. When I raised the point that vast amounts of money visibly has been disbursed in the two provinces and that, unlike in most other provinces, there are legal safeguards ensuring that only 'sons (and more seldom, daughters) of the soil' can run for local government offices such as governor, vice-governor, or district head, this was often brushed aside. My interlocutors tended to downplay the power of Papuan officials, portraying them as puppets of more powerful masters in Jakarta or in the security forces. The 'special autonomy elite', as Richard Chauvel calls them (2011: 107), have on the one hand been one of the main beneficiaries of Otsus funds but are also caught between pressures both from Jakarta and their local constituencies. 
violence, mostly in Papua province, including a multi-year series of shootings around the Freeport gold and copper mine in Timika, unresolved killings around Jayapura and ongoing attacks in Puncak Jaya. While a civil-society coalition together with a team from the Indonesian Institute of Sciences LIPI has been successful in bringing about some initial steps for a peaceful dialogue between representatives of Papuan society and the central government, most Papuans I interviewed put little faith into promises by the government, be it at the local, provincial or at the national level. ${ }^{13}$ It is in this atmosphere of mistrust, anxiety and suspicion but also hope of a resolution that my interviews were carried out.

\section{Israel as a perceived ally, and as a projection of hopes and aspirations}

Though by far not all references to Israel in my interviews had a political undercurrent, many interviewees likened their sense of the Papuan political struggle and sense of being under threat to the situation of the Jewish State. In these discourses, which are also prevalent among certain Christian groups in the West as well as in other parts of Indonesia, Judaism and Christianity are seen as being essentially 'on the same side'. ${ }^{14}$ Thus Israel and Papua find themselves as allies as well, especially with regard to the 'significant Other': Islam. Papuan informants described Israel as a righteous, plucky 'underdog', a 'small nation fighting against overwhelming odds' ${ }^{15}$

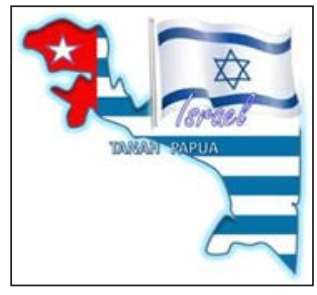

Figure 5.3. Banner of the website Papua-Israel News (http://papua-israel. blogspot.com), combining the Morning Star flag and Israeli flag with an outline of Tanah Papua. ${ }^{16}$

Source: http://papua-israel.blogspot.com (accessed 16.01.15).

13 For summaries of the dialogue process and Papua Road Map, see Tebay 2009 and Widjojo et al. 2008.

14 The simplistic dichotomy of Jewish Israel vs Muslim Palestine, and by extension Judeo-Christian West against Muslim Arabs, which is not uncommon in Western representations of the Israel-Palestine conflict, not only reduces a complex conflict to a clash of religions but also completely overlooks the fact that neither is the whole of the Palestinian population Muslim nor the Israeli population wholly Jewish.

15 Interviews, Jayapura and Manokwari.

16 Last accessed on 31.07.2013. 
The idea of fighting against the odds resonated with Papuans who said they were fearful of an Islamisation of their society, especially as Palestine is a cause célèbre among politically active Muslims in Indonesia. A direct comparison was made between how 'most of the lands described in the Bible had once been Christian (sic) and had now become Muslim', a portent for what was happening in Papua. ${ }^{17}$ Israel thus was seen as a substitute 'defender' of Jewish and Christian rights against perceived Muslim encroachment. ${ }^{18}$ Papua was described to me in one interview as being a 'lone Christian island surrounded by Muslims', and the thought of a powerful ally seemed to bring solace. ${ }^{19}$ Sometimes the view of the Jewish state as a 'natural ally' of Christian Tanah Papua manifested itself in rumours of Israeli assistance to the Papuan struggle. For example, some informants asserted that the Israeli secret service Mossad is purportedly helping the OPM. ${ }^{20}$

Some Papuans liken Israel's lack of recognition in the international community to West Papua's lack of recognition by the Indonesian state. As the website 'Papua-Israel News' (http://papua-israel.blogspot.com/), which advocates for a referendum, puts it:

West Papua and Israel share a common fate in the eyes of heathen (kafir) nations of the world, including Indonesia, because Indonesia and some other nations have not yet recognised the independence of the State of Israel on 14 May, 1948 and the independence of the State of West Papua on 1 December, 1961, hence our friendship and our struggle for the respect and self-regard of the two nations. ${ }^{21}$

Similar sentiments were also raised by Andrianus Merdhi in the short documentary film 'Der Schwarze Messias' ('The Black Messiah', 2010) which examines Papuans' identification with Israel. ${ }^{22}$ This imagined common fate of the States of Israel and West Papua, however, overlooks fundamental differences

17 Interview, Jayapura.

18 Interviews, Jakarta and Jayapura.

19 Interview, Jakarta.

20 Interviews, Brisbane (Australia), Jayapura and Sorong. The bitter irony is that if there is indeed any form of Mossad involvement, it is more likely not to be on the side of the Papuan nationalists but on the side of the Indonesian armed forces. Though there are no official links between the world's largest Muslim-majority nation and Israel, there are indications that unofficial links have existed between the Israeli secret service and Indonesian special forces Kopassus (Aditjondro 2000).

21 Original text: 'West Papua dan Israel punya nasib yang sama di mata negara-negara kafir di dunia termasuk indonesia, karena indonesia dan ada beberapa negara belum akui Negara Israel merdeka 14 mei 1948 dan Negara West Papua merdeka 1 Desember 1961, persabatan kami demi berjuang untuk kehormatan dan harga diri ke dua bangsa' (author's translation, last accessed 31.07.2013). There is a certain (unintended?) irony in the blogger's use of the Indonesian term 'kafir,'or unbeliever, to refer to those countries which have not recognised the State of Israel, as with the exception of North Korea these are Muslim-majority nations and the term kafir derived from the Arabic term رف kāfir, and usually is used in Islamic theology to refer to unbelievers in the sense of non-Muslims.

22 As interviewee Khaled puts it in the documentary, 'Israel and Papua face the same struggle for selfdetermination'. 
between the two with respect to international law. The Israeli government is de facto and de jure in control of its national territory. While several Papuan politicians claim to represent a government of a Free West Papua in exile, none of these can claim to control territory of significance. One hundred and fifty-seven states have full diplomatic relations with Israel and only 20 do not recognise Israel as a state; in contrast, only Vanuatu seems to support the West Papuan quest for self-determination. And although West Papuan independence has been declared several times, the raising of the Morning Star flag in front of the Nieuw Guinea Raad on 1 December 1961 was not one of these occasions. ${ }^{23}$

While the vast majority of my interviewees took a positive view of Israel, it is important to stress that amongst politically active Papuans this is not an uncontested view. As a student activist in Manokwari stated after he had listened in on my discussion with an older, pro-Israel Papuan leader:

I really don't understand this whole Israel thing. I mean, look at it: it's the Israelis that are taking away Palestinian land and the Israeli army is acting just like the TNI [Tentara Nasional Indonesia - Indonesian Armed Forces] is acting here, breaking human rights, shooting people ... If we're to identify with someone's struggle, then it's the Palestinians.

His fellow activist agreed and opined, unfortunately without wanting to elaborate any further:

I don't get it either ... but you know, I think it's mostly the older people who do it [display Israeli flags], and I guess the Baptists. It's like they expect some power from it. They're always going on about Israel, Israel, Israel ... but I don't really get it. I don't really know much about it.

Victor Yeimo, influential speaker of the Komite Nasional Papua Barat (KNPB National Committee of West Papua), also drew parallels to the Israeli occupation when comparing the Indonesian government's support of Palestinian statehood with its policies in Papua and West Papua (KNPB 2011). This is an interesting contrast with the West Papua National Authority (WPNA) ${ }^{24}$ statement below, given the generally close political ties between the two.

\footnotetext{
23 The Nieuw-Guinea Raad was a consultative body of indigenous Papuans established by the Dutch colonial government in the final stages of Dutch control over West New Guinea. On 1 December 1961, the national symbols of the territory were displayed publicly for the first time. These included the Morning Star flag, the anthem Hai Tanahku Papua and the Crowned Victoria Pigeon with an emblazoned Morning Star as a national coat of arms, which were to be used in conjunction with Dutch national symbols. In spite of the display of these national symbols, independence was only envisioned for the time after a 10-15 year period of transition (Saltford 2003: 9-12). Nonetheless, the date 1 December 1961 has entered Papuan political imagination as the date of the declaration of independence.

24 The WPNA is one of several umbrella organisations (such as the West Papua National Coalition for Liberation, WPNCL) which claim to be the legitimate representatives of the Papuan nationalist movement.
} 


\section{Spiritual links between Israel/the Holy Land and Papua}

A more spiritual reading of the relationship between Tanah Papua and Israel is based on views that the two areas are bound by a divine link. This is not always separable from a more political reading of the relationship. The 'God of Israel' and Jewish symbols such as the Star of David and the menorah are routinely used in conjunction with Christian and Papuan symbols, for example in signs denoting customary (adat) land or banners of the Dewan Adat Papua (DAP Customary Council of Papua), as visible in Figures 5.4 and 5.5.

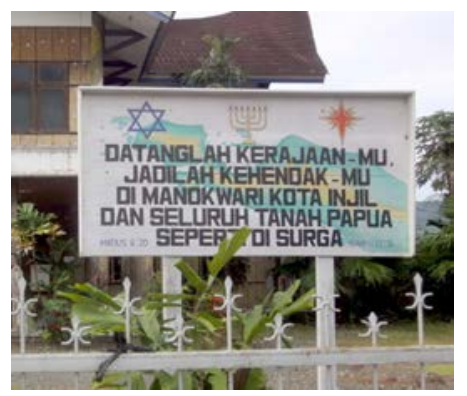

Figure 5.4. Office of the Dewan Adat Papua, Manokwari, West Papua. ${ }^{25}$

Source: Henri Myrttinen.

A further example of Papuans' invocation of Israel in the context of the nationalist struggle is illustrated in a recent speech by Reverend Terrianus Yoku, the President of the National Congress of the WPNA. Reverend Yoku who has taken to signing his proclamations as Reverend Israel Terrianus Yoku (my emphasis):

[...] Firstly - we must all give thanks to God in the name of Jesus Christ, the God of Israel, God of the Glorious Papuan Morning Star, the hero of the liberation of Papuans. [...] (WPNA, 2011)

The special link between Papuans and the Holy Land also manifests itself through pilgrimages to the Holy Land which informants said are becoming increasingly popular as Special Autonomy funds flow into the two provinces. ${ }^{26}$ In part, these have been organised by local politicians hoping to increase their standing with the electorate. ${ }^{27}$ The pilgrimages usually involve not only visits to the holy sites

25 The text on the banner reads 'Thy Kingdom come, thy Will be done, in Manokwari the City of the Gospel and across the Land of Papua as it is in Heaven'.

26 Unfortunately, I was not able to come by reliable figures and some of the figures given by interviewees seemed inflated.

27 Interviews, Manokwari and Wuppertal (Germany). 
but also a baptism in the River Jordan. ${ }^{28}$ One pilgrimage in particular seems to have captured the public imagination, when a delegation of 34 Papuans donated a kilogramme of gold from Papua and an undisclosed sum of money for the reconstruction of the Third Temple on the Temple Mount in Jerusalem (HaLevi 2007). ${ }^{29}$ The story of Papuans bringing gold to the Holy Land was related to me by several interviewees, though they described the donation as supporting the building of 'a golden bridge' from Papua to the Holy Land in anticipation of the Second Coming of Jesus Christ, rather than the reconstruction of the Temple. ${ }^{30}$

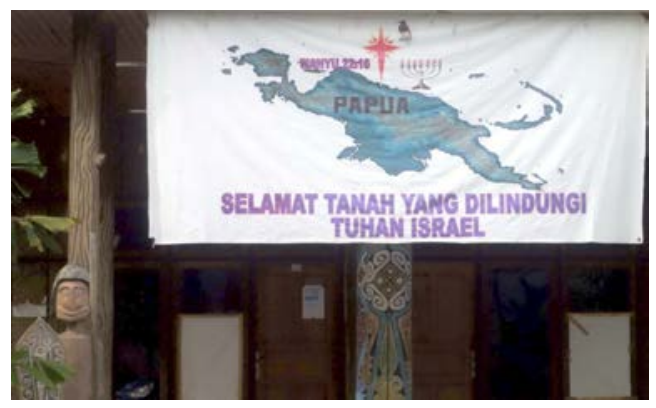

Figure 5.5. Office of the Dewan Adat Papua, Manokwari, West Papua. ${ }^{31}$

Source: Henri Myrttinen.

Many of the links between Tanah Papua and the Holy Land can be traced back to local readings and interpretations of the Scriptures. Glazebrook (2008: 146147) traces one of these sources to a Dutch pastor whose sermon was influential in the West Papuan refugee camps in Papua New Guinea:

A schoolteacher at East Awin explained Leenhout's revelation to me. In 1948, the pastor apparently received divine revelations relating to Romans 9 and 11, and Ephesians 2:11-22 in the New Testament. The revelation occurred at the time of two significant events, both involving Israel. First, at the formation of the World Council of Churches its membership included churches that did not recognise Jesus as Messiah. Second, Israel's constitution as a political state denied its non-secular nature as Promised Land. Leenhout preached that Israel was a window through which God viewed the world but while Israel remained a political state, peace would elude the world. God had intentionally hardened the heart of Jews so that Christ's teachings would be spread to

\footnotetext{
28 Interviews, Jayapura and Manokwari, as well as Merdhi (2010).

29 According to the Israeli news article on the event (HaLevi, 2007), the Papuans were inspired by the Biblical verse Zechariah (6:15), 'And the distant ones will come and build the Temple of God'. The gold and funds for the controversial project were given to the Temple Institute.

30 Interviews, Jayapura and Sorong.

31 The text on the banner reads 'Hail the Land which is protected by the God of Israel'.
} 
other nations. The salvation of black colonised nations, including West Papua, was said to be wrapped up in the fate of Israel, and it was the responsibility of the peoples of these nations to evangelise Israel.

In fact, Leenhout's sermon made scant reference to West Papua. So we might deduce that the West Papuan translator, himself a pastor, as well as congregation leaders and followers at East Awin, have interpreted Leenhout in light of their own theological and political standpoints.

The (re-)reading of Leenhout's sermon described here by Glazebrook with its implicit obligation for Papuans to go to Israel and evangelise is similar to the views which I encountered in some interviews that the Star of David is actually the Morning Star which was taken by Israel from Papua and needs to be 'returned'. ${ }^{32}$ There are definite echoes here of Rutherford's (2003) 'Raiding the Land of the Foreigners' as well as Kirksey (2012: 29-33) and the links they draw to the millenarian Koreri cycle, though one needs to be cautious with transposing a Biak-Numfor area myth directly into other Papuan cultural contexts. ${ }^{33}$ The Morning Star, prominently displayed on the Papuan flag, plays a central role in the Koreri cycle of myths which, above caveats in mind, has been a source of inspiration for Papuan nationalist movements (Kamma 1972; Rutherford 2003 and 2012; see also below for a more detailed discussion of the Koreri movement). ${ }^{34}$

The notion that powerful symbols have been misappropriated from Tanah Papua by outsiders is also raised by Glazebrook (2008), Kirksey (2012) and Timmer (2000), e.g. with respect to the Indonesian state symbols such as the Garuda.

The spiritual linking of Tanah Papua with Israel is thus strongly intertwined with Christianity or, more precisely, Papuan readings of Christianity in which the belief systems introduced by outside missionaries are reinterpreted locally, be it through myths (e.g. reading Biblical stories and the role of Israel/The Holy Land through the Koreri lens, as it were) or through more confrontational approaches where outsiders, including Israel, are accused of having misappropriated powerful Papuan symbols. In the next section, I shall examine a further understanding of the Papuan-Israeli relationship, one in which the distinction between the two becomes more blurred.

\footnotetext{
32 Interviews, Manokwari.

33 The Koreri cycle, in brief, tells the story of the mythical hero Manarmakeri who, having been banished by his fellow villagers, travels the world bringing knowledge and riches to foreign lands, and whose return home is to usher in a new era of plenty. For far more in-depth, nuanced and complex explorations of Koreri than can be presented here, see Kamma (1972) and Rutherford (2003 and 2012: 91-124). Both Kirksey (2012: 31 and 243-244) and Rutherford (2012: 103) point to Biak readings of Manarmakeri being equated with the Father of, and/or with Jesus Christ.

34 Not all Papuan political leaders whom I interviewed, however, saw the Morning Star as a symbol of Papuan aspirations for merdeka. One leader who associates himself with the Pan-Melanesian 14 Star Movement regarded the Morning Star as a 'symbol of Lucifer'. Interview, Melbourne.
} 


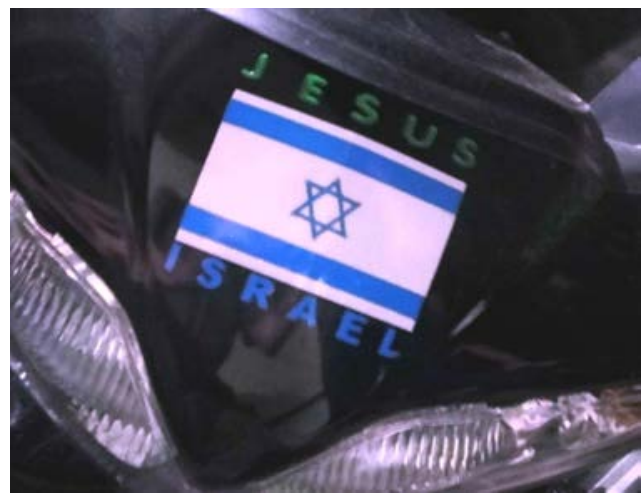

Figure 5.6. Motorbike decal in Jayapura, Papua.

Source: Henri Myrttinen.

\section{Israel/the Holy Land as (metaphor for) Tanah Papua}

The third kind of discourse around Israel/Tanah Papua focuses on the metaphorical level. This covers a spectrum of understandings, starting with the use of Biblical references in everyday speech to more literal readings of Biblical events as having happened, happening or going to happen in the Land of Papua. It was not always possible in all my interviews to draw a distinct line between where events in Papua were merely compared to those occurring in the Bible and narratives in which Biblical events were actually considered to have happened in Papua. ${ }^{35}$ For the most part, though, Biblical events were 'left' in the Holy Land but used as a point of comparison for the situation in Papua and West Papua (on the use of Biblical language, see also Timmer 2000: 233). Given widespread Papuan sentiments of marginalisation and oppression, a common theme was that of exile and captivity, be it the Biblical story of exile in Egypt or in Babylon, a thematic undercurrent also visible for example in Afro-American and Afro-Caribbean Christianity. ${ }^{36}$ These stories were invoked in part when discussing the overall situation of the Bangsa Papua or personal captivity. ${ }^{37}$

\footnotetext{
35 The distinction between the two may be one that only seems pertinent from my Western perspective.

36 Interviews, Jayapura and Wuppertal. Timmer (2000: 297-300) also discusses Imyan conceptualisations of the Tower of Babel having been built in Baimla.

37 Interviews, Port Moresby (Papua New Guinea), Port Vila (Vanuatu) and Jayapura.
} 


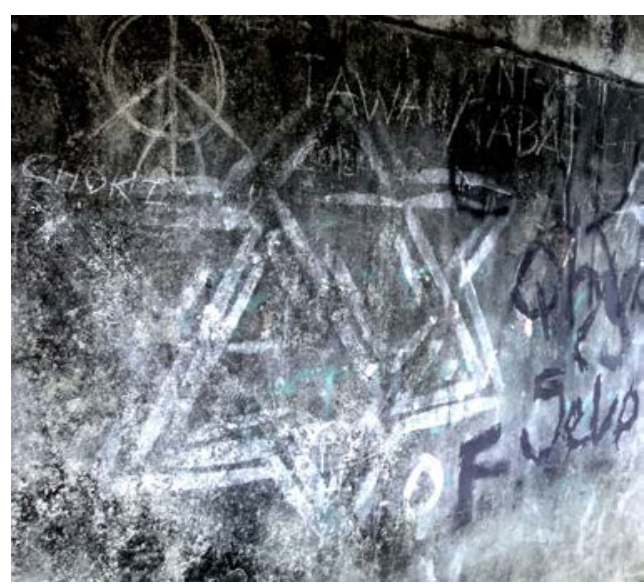

Figure 5.7. Star of David graffiti, Jayapura, Papua.

Source: Henri Myrttinen.

As Diana Glazebrook (2008: 146) relates in her study of West Papuan refugees planning to return to Indonesia from refugee camps in PNG, the theme of Moses and return from exile can go beyond the strictly metaphorical to a more personalised and localised reading, though with a globalised twist. In this case, the Moses trope was projected onto the persona of a refugee evangelical pastor, Jeronimus, who had established the West Papua Indigenous Peoples' Association (WPIA) after receiving mail from a transnational forum of indigenous people based in Geneva:

Jeronimus was hailed as a Moses figure by his WPIA constituency: In the story of Exodus, through the prophet Moses, God performed ten miracles of plagues and still Pharoah was hard hearted, refusing to let the Israelis out of Egypt. The Israelis were slaves. Suharto was like Pharaoh. Jeronimus is a prophet and deliverer like Moses. As we have seen from the history of Israel, Moses led them home. West Papuan people can similarly be saved.

[...] In a 1998 Christmas sermon posted to East Awin, the translated sermon mentioned the government of Israel's plea for members of the Jewish diaspora to return to Israel to help develop their nation. WPIA leaders interpreted this sermon analogously as a call for West Papuans to return to Irian Jaya to assist develop the nation-state, ${ }^{38}$ rather than return in its wake. The idea of connection between Irian Jaya and Israel may

38 Based on Glazebrook's text, there seemed to be differing readings among the West Papuan refugee community as to whether this referred to returning to help re-build an Indonesian-controlled Irian Jaya, as advocated by Jeronimus, or an independent West Papua as argued by his detractors. 
have been influenced by a publication titled 'From Jerusalem to Irian Jaya' which had been advertised and reviewed in the Catholic weekly Tifa Irian, a newspaper that occasionally circulated at East Awin. While I knew of no copies of the book at East Awin and knew of no-one who had read the book, many people referred to its title.

As outlined by Jaap Timmer (2000: 285, 297-300) in his study of the Imyan in West Papua, Biblical stories and Biblical locations can also be taken beyond the merely comparative and be redefined as having actually taken place in Tanah Papua. In 2008 and 2009, a religious movement in the Mamberamo area was also based on reinterpreting Biblical events in the context of Papuan political struggles. Inspired by the visions of an elderly lady from Biak, Nela Yanseren, a group of armed civilians who identified with the OPM occupied an airfield in Kapeso in expectation of the Second Coming of Christ and Papuan independence. In Ibu (Mrs or Mother) Nela's visions, the Mamberamo River was recast as the River Jordan, the nearby Lake Rombebay was the Sea of Galilee and the OPM military commander Richard Yoweni was cast as Moses who has led his people through the Wilderness for 40 years but could not cross into the Promised Land. Instead, it would be up to the armed men led by Decky Imberi, now cast as Joshua and calling his men the Army of Joshua, to lead the people out of slavery. The struggle against the Indonesian state was stated by Ibu Nela as being a precondition for the Second Coming of Christ (KMSKP 2009 and KPKC 2009).

The Kapeso airfield occupation is not the first case of a millenarian movement in the Mamberamo area. ${ }^{39}$ Freerk Kamma (1972: 294-298) documents a movement in the region in 1956-62 but the more obvious parallels are with the Koreri movement in the Biak-Numfor area in 1938-44. As outlined in Kamma (1972: 157-213) and also Rutherford (2003: 24-28, 2012: 157-161), the movement combined religious elements from Christianity with local mythology, in which a local culture hero Manarmakeri is to return to Papua with the promise of material wealth and eternal life, secrets which the Morning Star had bestowed upon him. Though similar movements were far from uncommon (Kamma alone lists several dozen cases), the Koreri movement was not only marked by longevity but also by an explicitly political agenda of an independent New Guinea under the leadership of Angganitha Manufaur, who also bore the title Bin Damai ro Judea (Woman of Peace from Judea) and Ratu Mas ro Judea (Golden Queen of Judea). Like Ibu Nela, she had a following of an army of sorts and, as in the case of the Kapeso airfield occupation, sites from the Holy Land were 'relocated' to Papua: Judea was the island of Insumbabi and Bethlehem the island of Aiburanbondi, both off the coast of Biak. In an effort to appease Manseren, who was to return to

39 Kirksey (2012: 46-50) and Rutherford (2003: 13-19 and 2012: 91-124) have also pointed to millenarian elements in the events which preceded the 'Bloody Biak' massacre of 1998, although Rutherford stresses that the central figure in the flag-raising, Filep Karma, did not himself draw any links to the Koreri movement. 
Insumbabi/Judea, amongst other things the consumption of pork was forbidden (Kamma 1972: 159-160). Rutherford (2012: 157-164) furthermore stresses the 'power of the foreign' that the Koreri movement sought to harness, linked here directly with the Biblical Holy Land. Both the Kapeso airfield occupation and the Koreri movement ended at the hands of security forces without reaching their goals of a millenarian solution to the political status of Papua.

\section{Discussion}

I have thus far sketched some of the ways in Papuans link Israel and the Holy Land to Tanah Papua and to Papuan aspirations for merdeka, whichever form this freedom might be imagined to manifest itself in. Papuan re-readings of Israel, the Holy Land and events of the Bible are complex, overlapping and in part contradictory. For example, the stories of Moses, the Exodus and entering the Promised Land are reflected in Papuan stories of returning refugees (Glazebrook 2008) and occupying Kapeso airfield, but they came to opposite conclusions. Returning refugees saw the Biblical narrative as an exhortation to return to the Indonesian state, while the Kapeso airfield occupants interpreted the story as an instruction to struggle against it. Both groups, however, interpreted Papua as the Promised Land of Biblical stories.

In Papuan discursive engagements with Israel, either as a beleaguered Jewish/ Christian nation-state, or as the Holy Land, we may see what seem like elusive symbolic interpretations, contradictions and leaps of faith. However, Papuan understandings of Israel/the Holy Land should be interpreted in terms of local logic and experience. Israel and the Holy Land are seen in these re-readings from a very Papuan perspective which is informed by Christianity and local mythology such as Koreri, a history of oppression and marginalisation of the indigenous population, fears of the loss of Papuan identity through an influx of Muslim migrants, and limited possibilities of having open, critical and informed political discussions on issues feeding Papuan discontent.

When Papuans emphasise the special relationship of Papua to a perceived centre of power, we may read this as an attempt to escape marginality and regain agency (Timmer 2000). Drawing on the potency of perceived allies who (often without knowing it) are seen to share a special relationship, the mostly forgotten Papuan political struggles start taking centre stage, at least from the Papuan perspective.

It is not only Israel which is seen as possessing power that, possibly, was once in the hands of Papuans and was misappropriated by outsiders, a theme also 
encountered in the Koreri myths. Papuans also invoke Dutch, Indonesian and American, and United Nations symbols of sovereignty. As Glazebrook (2008: 145) discusses,

Other WPIA members attributed a kind of supernatural agency to UN paraphernalia like logos — as though they were enspirited ... Like the UN logo, national flags were considered to have a sort of human agency, or witnessing capacity.

The potency of Dutch, American, Indonesian and UN symbols can be seen in the context of Papuan history: it was these powers that played key roles in the events, perceived by many of my interviewees as 'traumatic', through which Dutch West New Guinea became the Indonesian province of Irian Jaya, and these powers should now undo the damage done. Though Israel has played no role in the historical events of the past 50 years that have shaped Tanah Papua, it is perceived as an ally. The most obvious link from the Papuan perspective is religion: Judaism and Christianity are seen as being on the same side of a struggle against creeping Islamisation. Doctrinal differences between Judaism and Christianity are glossed over as are differences in terms of the de facto and de jure political status of the State of Israel and Tanah Papua. Israel (rather than, for example, Palestine) is seen as a righteous underdog in this struggle, but nonetheless as a powerful underdog. Non-recognition of Israel and of West Papuan ambitions for merdeka by the Indonesian state are at times conflated. Israel thus becomes an inadvertent ally for some (i.e. those not seeing more of a parallel with Palestine), its national symbols signifying opposition to perceived Islamisation and, in some cases, the policies of the Indonesian government (Merdhi 2010).

Other understandings of the special relationship are more bound to Christian practice, such as making a pilgrimage to the Holy Land and an adult baptism in the River Jordan. Biblical stories and metaphors, which are often the most accessible texts especially in villages, are used to make sense of a social, political and economic situation that seems inherently skewed against Papuan aspirations. References to Jewish captivity in Egypt and Babylon have a special resonance among my Papuan informants.

In some cases, as with Papuans' donation to the construction of the Third Temple and the (possibly apocryphal) notion of building a golden bridge for the Second Coming, there is a clear break with mainstream Christian orthodoxy. Even more complex understandings of the special relationship are found in millenarian movements such as Koreri and in what happened more recently in Kapeso. Here Christian eschatology became mixed with local mythology and Papuan political aspirations, taking place in a Tanah Papua which has become, at least in part, the Promised Land. 
In all their complexity and richness, the multiple Papuan narratives linking Tanah Papua with Israel and the Holy Land are about aspirations of Papuans towards merdeka - whatever form this merdeka is expected to take. Israel, without knowing it, is at times seen as a potent ally, a source of spiritual power and solace, and at times Papua becomes the Holy Land and the Holy Land becomes Papua. Based purely on my own observations in Papua, but also in other parts of eastern Indonesia, the centrality of Israel in Christian discourses and also visually, especially in urban areas, seems to be increasing. In part, this may be part due to a heightened religious polarisation in the country, but also due to increased use of internet-based media and organised pilgrimages to the Holy Land. As I hope to have sketched here, however, these discourses are not straightforward or uncontested among Papuans. Rather, Papuan narratives linking Tanah Papua with Israel and the Holy Land involve numerous different voices, bringing together local mythology, understandings of Christianity, political aspirations and readings of global politics.

\section{References}

Aditjondro, George 2000. 'Ninjas, Nanggalas, Monuments and Mossad Manuals - An Anthropology of Indonesian State Terror in East Timor'. In Sluka, Jeffrey (ed.), Death Squad: The Anthropology of State Terror. Philadelphia: University of Pennsylvania Press, 158-188.

Anderson, Benedict 2005. Under Three Flags: Anarchism and the Anti-Colonial Imagination. London: Verso.

Bubandt, Nils 2008. 'Rumors, Pamphlets, and the Politics of Paranoia in Indonesia'. The Journal of Asian Studies 67(3): 789-817.

Chauvel, Richard 2006. 'Violence and Governance in West Papua'. In Coppel, Charles (ed.), Violent Conflicts in Indonesia: Analysis, Representation, Resolution. London: Routledge, 180-191.

Chauvel, Richard 2011. 'Policy Failure and Political Impasse: Papua and Jakarta a decade after the "Papuan Spring"'. In King, Peter, Elmslie, Jim and WebbGannon, Camellia (eds), Comprehending West Papua. Sydney: University of Sydney, 105-115.

Drooglever, Pieter 2005. Een Daad van Vrije Keuze: De Papoea's van Westelijk Nieuw-Guinea en de Grenzen van het Zelfbeschikkingsrecht. Amsterdam:Uitgeverij Boom.

GKI 2011. 'The Third Papuan Congress and The Declaration of Independence.' Report by KPKC, Synod of GKI, Jayapura, 21 October, 2011. 
Glazebrook, Diana 2008. Permissive Residents: West Papuan Refugees Living in Papua New Guinea. Canberra: ANU Press.

HaLevi, Ezra 2007. 'West Papua Delegation Donates Gold For Holy Temple'. Arutz Sheva. http://www.israelnationalnews.com/News/News.aspx/123837 (accessed 10 July 2007).

Jebens, Holger 2004. 'Introduction'. In Jebens, Holger (ed.), Cargo, Cult, and Culture Critique. Honolulu: University of Hawai'i Press, 1-13.

Kamma, Freerk 1972. Koreri-Messianic Movements in the Biak-Numfor Culture Area. Den Haag: Martinus Nijhoff.

Kammen, Douglas 2009. 'Fragments of Utopia: Popular Yearnings in East Timor'. Journal of Southeast Asian Studies 40(2): 385-408.

Kirchhoff, Karl-Heinz 1973. Die Täufer in Münster 1534/35: Untersuchungen zum Umfang und zur Sozialstruktur der Bewegung. Münster: Aschendorff.

Kirksey, Eben 2012. Freedom in Entangled Worlds: West Papua and the Architecture of Global Power. Durham: Duke University Press.

KMSKP 2009. 'Gerakan Kargoisme Yang Dibelokan Oleh Gerakan Atas Nama OPM di Kapeso'. Jayapura: Koalisi Masyarakat Sipil Untuk Keadilan dan Perdamaian di Tanah Papua.

KNPB 2011. 'Indonesia backs Palestine at UN, what about West Papua?' Press Release: West Papua Media Alerts, 21 September 2011.

KPKC 2009. 'Bentrok di Kapeso, 4 Warga Papua Tewas'. Jayapura: KPKC Sinode GKI di Tanah Papua.

Merdhi, Andrianus 2010. Der Schwarze Messias. Documentary film accessed at http://vimeo.com/25197078.

Myrttinen, Henri 2010. Histories Of Violence, States of Denial-Militias, Martial Arts And Masculinities In Timor-Leste. Ph.D. Thesis, Durban: University of KwaZulu-Natal.

Ondawame, John Otto 2010. One People, One Soul - West Papuan Nationalism and the OPM. Adelaide: Crawford House Publishing.

Reagan, Ronald 1984. 'Remarks Accepting the Presidential Nomination at the Republican National Convention in Dallas, Texas, August 23, 1984'. Transcript accessed at http://www.reagan.utexas.edu/archives/speeches/1984/82384f. htm. 
From 'Stone-Age' to 'Real-Time'

Rutherford, Danilyn 2003. Raiding the Land of the Foreigners: The Limits of the Nation on an Indonesian Frontier. Princeton: Princeton University Press.

Rutherford, Danilyn 2012. Laughing at Leviathan: Sovereignty and Audience in West Papua. Chicago: Chicago University Press.

Saltford, John 2002. The United Nations and the Indonesian Takeover of West Papua, 1962-1969: Anatomy of a Betrayal. London: Routledge.

Swazey, Kelli 2010. 'Circulating Israel in Indonesia: Publics of Pilgrimage and National Christian Subjecthood in North Sulawesi'. Paper presented at the American Anthropological Association Annual Meeting, New Orleans, 17 November, 2010.

Tebay, Neles 2009. Dialog Jakarta-Papua: Sebuah Perspektif Papua. Jayapura: SKP.

Timmer, Jaap 2000. Living With Intricate Futures - Order and Confusion in Imyan Worlds, Irian Jaya, Indonesia. Nijmegen: University of Nijmegen.

Timmer, Jaap 2008. 'Kastom and Theocracy: A Reflection on Governance from the Uttermost Part of the World'. In Dinnen, Sinclair and Firth, Stewart (eds), Politics and State Building in Solomon Islands. Canberra: ANU Press, 194-212.

Widjojo, Muridan S., Elisabeth, Adriana, Amiruddin, Pamungkas, Cahyo and Dewi, Rosita 2008. Papua Road Map: Negotiating the Past, Improving the Present and Securing the Future. Jakarta: Indonesian Institute of Sciences, Jakarta.

WPNA 2011. 'WPNA Rejects LIPI-Peace Network Conference Because West Papua Is An International Issue Requiring International Third Party Mediation.' Press Release, Yapen Waropen Mamberamo, 6 July 2011. 
This text is taken from From 'Stone-Age' to 'Real-Time': Exploring Papuan Temporalities, Mobilities and Religiosities, edited by Martin Slama and Jenny Munro, published 2015 by ANU Press, The Australian National University, Canberra, Australia. 